\title{
Quantification of Methane and Ammonia Emissions in a Naturally Ventilated Barn by Using Defined Criteria to Calculate Emission Rates
}

\author{
Alexander J. Schmithausen ${ }^{1, *(1)}$, Inga Schiefler ${ }^{2}$, Manfred Trimborn ${ }^{1}$, Katrin Gerlach ${ }^{3}$ (D), \\ Karl-Heinz Südekum ${ }^{3}{ }^{(D}$, Martin Pries ${ }^{4}$ and Wolfgang Büscher ${ }^{1}$ \\ 1 Institute of Agricultural Engineering, University of Bonn, Nußallee 5, 53115 Bonn, Germany; \\ m.trimborn@uni-bonn.de (M.T.); buescher@uni-bonn.de (W.B.) \\ 2 Association for Bioeconomy Research (FBF), Adenauerallee 174, 53113 Bonn, Germany; si@fbf-forschung.de \\ 3 Institute of Animal Science, University of Bonn, Endenicher Allee 15, 53115 Bonn, Germany; \\ kger@itw.uni-bonn.de (K.G.); ksue@itw.uni-bonn.de (K.-H.S.) \\ 4 Chamber of Agriculture of North Rhine-Westphalia, Ostinghausen, 59505 Bad Sassendorf, Germany; \\ martin.pries@lwk.nrw.de \\ * Correspondence: schmithausen@uni-bonn.de; Tel.: +49-228-73-3048
}

Received: 5 March 2018; Accepted: 13 May 2018; Published: 16 May 2018

Simple Summary: Defined criteria for the application of the $\mathrm{CO}_{2}$ balance method in a naturally ventilated barn provided reliable data. This specification enabled the acquisition and quantification of $\mathrm{CH}_{4}$ and $\mathrm{NH}_{3}$ in a naturally ventilated dairy barn, as well as detecting decreasing $\mathrm{NH}_{3}$ emissions affected by supplementing an Acacia mearnsii condensed tannin extract to a dairy cattle ration. Moreover, long-term measurements were possible and can be used to examine feed-related mitigation strategies at a barn level in the future.

\begin{abstract}
Extensive experimentation on individual animals in respiration chambers has already been carried out to evaluate the potential of dietary changes and opportunities to mitigate $\mathrm{CH}_{4}$ emissions from ruminants. Although it is difficult to determine the air exchange rate of open barn spaces, measurements at the herd level should provide similarly reliable and robust results. The primary objective of this study was (1) to define a validity range (data classification criteria (DCC)) for the variables of wind velocity and wind direction during long-term measurements at barn level; and (2) to apply this validity range to a feeding trial in a naturally cross-flow ventilated dairy barn. The application of the DCC permitted quantification of $\mathrm{CH}_{4}$ and $\mathrm{NH}_{3}$ emissions during a feeding trial consisting of four periods. Differences between the control group (no supplement) and the experimental group fed a ration supplemented with condensed Acacia mearnsii tannins (CT) became apparent. Notably, CT concentrations of $1 \%$ and $3 \%$ of ration dry matter did not reduce $\mathrm{CH}_{4}$ emissions. In contrast, $\mathrm{NH}_{3}$ emissions decreased $34.5 \%$ when $3 \% \mathrm{CT}$ was supplemented. The data confirm that quantification of trace gases in a naturally ventilated barn at the herd level is possible.
\end{abstract}

Keywords: emission; dairy cows; greenhouse gas; tannin

\section{Introduction}

Environmental problems and emissions from agriculture are a topic with global significance and potential long-term consequences and are discussed by policy-makers and consumers [1,2]. Agriculture has to contribute to the mitigation of greenhouse gas (GHG) and $\mathrm{NH}_{3}$ emissions. In Europe, agriculture, in particular dairy farming, is the biggest source of $\mathrm{NH}_{3}$ emissions [3], which occur during slurry management but also directly out of the barn [4-7]. The potential of different mitigation measures, 
such as feeding strategies, on GHG emissions from naturally ventilated animal buildings is difficult to quantify [8]. Data available from the Intergovernmental Panel on Climate Change (IPCC) in particular are based on chamber measurements [9]. Here, data are mostly from theoretically calculated values or based on short-term measurements [10,11]. At the individual animal level, measurements of $\mathrm{CH}_{4}$ emissions from enteric fermentation in respiration chambers have been suitable to date [12]. The environmental conditions in a respiration chamber are strictly standardisable [9]. However, this method is cost- and labour-intensive and the natural behaviour of the animals is influenced $[9,13,14]$. Respiration chambers are rather unsuitable for the determination of $\mathrm{NH}_{3}$ emissions, because the influence of and interactions among animal activities, excrements, barn surfaces, weather effects and management are inadequately reflected in the measurements [4]. Further methods for measuring GHG in the natural environment of the animals include automated head chamber systems such as GreenFeed or the $\mathrm{SF}_{6}$ technique $[15,16]$. Such techniques are suitable for spot measurements of $\mathrm{CH}_{4}$ during pasture conditions or within the barn. However, especially for the GreenFeed system, it is a challenge to achieve data of all cows in a group of animals spread out over $24 \mathrm{~h} \mathrm{[16].} \mathrm{Furthermore,}$ systems in conjunction with the individual animal neglect the GHG of the husbandry environment and excrements as well as additional trace gases such as $\mathrm{NH}_{3}$. More information on measurement systems are described by $[11,16]$. Therefore, measurements in the barn environment are necessary [17-19]. The determination of the ventilation rate $(V R)$ in naturally ventilated buildings is a key factor for quantifying emissions from livestock buildings [20].

One of the methods routinely used to determine the $V R$ in naturally ventilated barns is the tracer gas decay technique. For this procedure, several gases have been used: $\mathrm{CO}$ [21], ${ }^{85} \mathrm{Kr}$ [22], $\mathrm{N}_{2} \mathrm{O}$, and $\mathrm{SF}_{6}[23,24]$. The $V R$ can be calculated from the dilution of the dosed gases. It is difficult to realise a homogeneous distribution of the dosed trace gas [25], and $\mathrm{SF}_{6}$ is a GHG which is not produced by the animals in the barn, such as moisture, heat [20,22], or $\mathrm{CO}_{2}$ [26-28]. The $\mathrm{CO}_{2}$ balance method is the most commonly used. If the theoretical $\mathrm{CO}_{2}$ emission within the barn is known, based on the number of animals and individual animal characteristics (body weight (BW), lactation period), the $V R$ can be quantified by reference to the actual $\mathrm{CO}_{2}$ concentration within the barn and consideration of the barn level $[8,20,28]$.

Nevertheless, there is a lack of long-term measurements relative to selective short-term measurements or simulations [29,30]. Only a few studies have investigated the gaseous emissions from livestock buildings and their environmental implications based upon the $\mathrm{CO}_{2}$ balance method and defined measurement periods $[4,17,31]$. Little attention has been paid to the accuracy of long-term measurements including the corresponding basal, varying conditions. Long-term measurements involving feeding strategies for GHG mitigation under similar conditions (weather conditions, $V R$ ) are also still missing. Additionally, it is a challenge to adjust the methodology taking into account wind velocity and wind direction [31], which may largely impact the $V R$.

The main objectives of the present study were (1) to define a range of values for the $\mathrm{CO}_{2}$ balance method based on weather conditions, namely minimum wind velocity and the wind direction, which allow a reliable quantification of the $V R$ in a specific naturally ventilated barn; (2) to quantify emission rates of $\mathrm{CH}_{4}$ and also $\mathrm{NH}_{3}$ on the herd level based on long-term measurements with robust and clearly defined values using the $\mathrm{CO}_{2}$ balance method combined with daily individual animal information such as dry matter intake (DMI); and (3) to evaluate $\mathrm{CH}_{4}$ and $\mathrm{NH}_{3}$ emissions in a naturally ventilated dairy barn by feeding a ration supplemented with selected secondary plant compounds under case-control conditions.

\section{Materials and Methods}

The study was conducted in a naturally ventilated dairy barn at the Experimental and Educational Centre for Agriculture 'Haus Riswick', Chamber of Agriculture of North Rhine-Westphalia, over a period of six months, during both the summer and winter seasons. The barn is located in Kleve, Germany $\left(51^{\circ} 47^{\prime} 18^{\prime \prime} N\right.$, $\left.6^{\circ} 8^{\prime} 19^{\prime \prime} \mathrm{E}\right)$. 


\subsection{Experimental Building and Measurement Technique}

The dairy barn is a cross-flow ventilated building, with dimensions (length $\times$ width) of $68 \mathrm{~m} \times 34 \mathrm{~m}$. The eave height is $5.15 \mathrm{~m}$ and the ridge height is $12.35 \mathrm{~m}$. The internal room volume of the barn is $21,000 \mathrm{~m}^{3}$. The ventilation was operated manually by adjusting the curtains on the western eave sides according to the prevailing weather conditions. The curtains were closed during the winter period, and in spring (10 March-16 April 2013) and summer (as from 16 April 2013), the curtains were half- or fully-opened. The building is spatially separated into three different sections with different air spaces. The measurements of this study were performed in Sections 1 and 2 (Figure 1), which were equipped with identical, slatted floors and an under-floor concrete slurry storage system (1.6 m depth). Sawdust was used as bedding material in the raised cubicles. The experimental barn was equipped with individual animal identification of water and feed intake as well as case control conditions of the gas measurements.

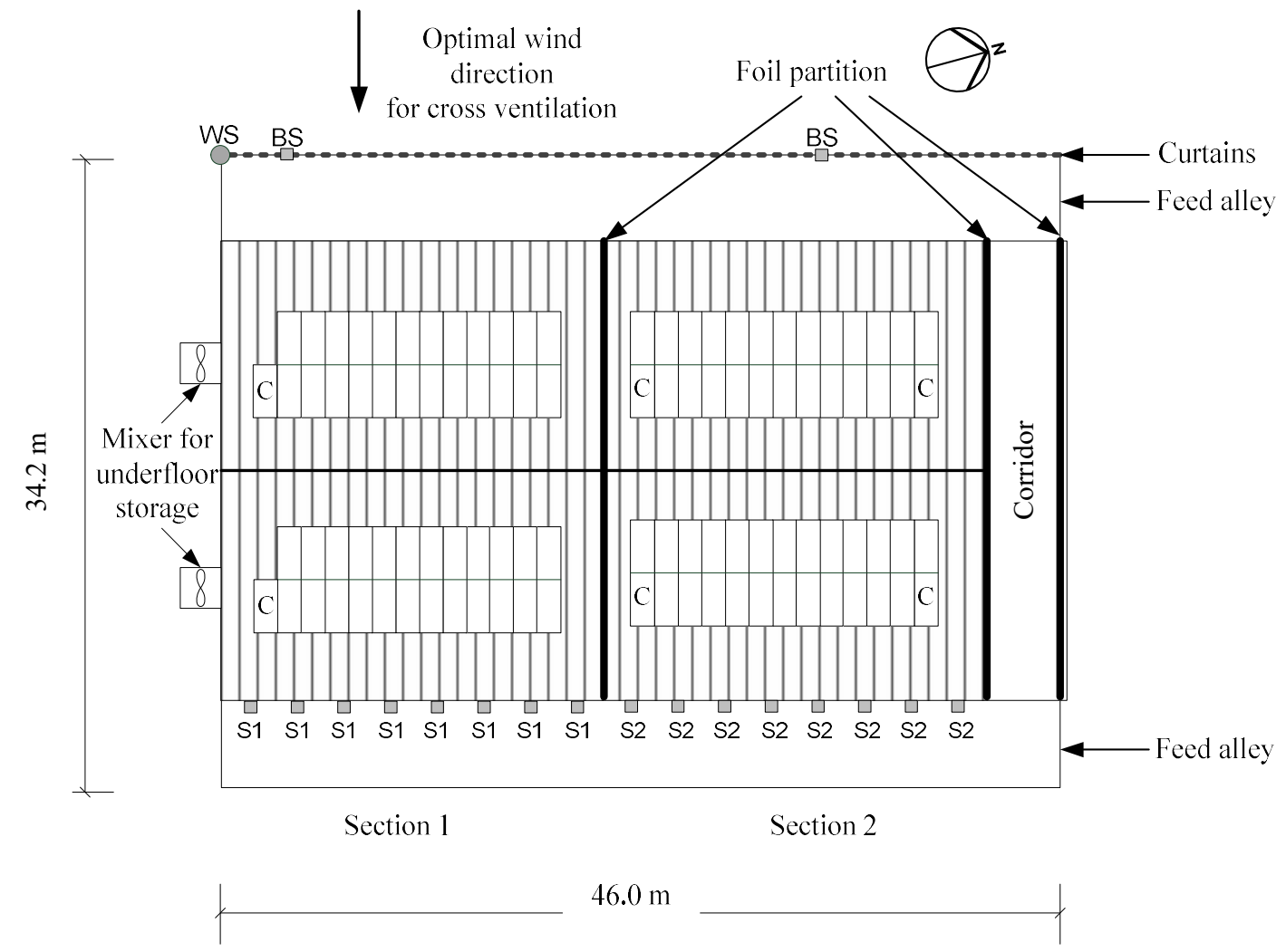

Figure 1. Construction plan of the barn and the slurry storage systems. Sections 1 and 2 have slatted floors. The level of slurry homogenisation varied among Sections 1 and 2. WS: weather station, located on the rooftop of the western eave; BS: background sampling points; S1-S2: sampling points (Sections 1 and 2) of the gases, described in the text; C: concentrate stations; small rectangles: slatted floor; wide rectangles: bedding area.

The slatted floor sections were cleaned four times per day using an automated cleaning robot with a water-spray device (Joz Tech JT100, Joz B.V., Westwoud, The Netherlands). Only the intensity of slurry homogenisation was slightly more intensive for Section 1 than Section 2 due to the mixer position at the gable wall of the building. The slurry was homogenised about ten times over the whole period. Because homogenisation of slurry increases emissions of trace gases, this period and a minimum of $12 \mathrm{~h}$ afterwards were not included in data analysis. Slurry was not removed during the experiment. 


\subsection{Measurement Concept}

Measurement of $\mathrm{CO}_{2}, \mathrm{CH}_{4}$, and $\mathrm{NH}_{3}$ concentrations to determine the $\mathrm{CH}_{4}$ and $\mathrm{NH}_{3}$ emissions were carried out in Sections 1 and 2 of the barn from 8 January to 25 June 2013, which included cold and warm periods. The overall experimental period was approximately 24 weeks (169 days) and was divided into four periods to examine different ration treatments (Table 1).

Table 1. Description of the measurement periods and conditions (average values of each measurement period for both barn sections). DM: dry matter.

\begin{tabular}{lccccc}
\hline Period & Time of the Measurement Period & $\begin{array}{c}\text { No. of } \\
\text { Days }\end{array}$ & $\begin{array}{c}\text { Concentration } \\
\text { of Tannins } \\
\text { (\% of DM) }\end{array}$ & $\begin{array}{c}\text { Temperature } \\
\text { during Measure } \\
{ }^{\circ} \text { C (SD) }\end{array}$ & $\begin{array}{c}\text { Wind Speed }{ }^{2} \\
\text { during Measure } \\
\text { m/s (SD) }\end{array}$ \\
\hline Period 1 (CT0) & 8 January 2013-4 February 2013 & 28 & 0 & $4.4(3.9)$ & $2.2(1.1)$ \\
Period 2 (CT1) & 5 February 2013-18 March 2013 & 42 & 1 & $4.9(2.7)$ & $1.7(0.6)$ \\
Period 3 (CT3) & 19 March 2013-20 May 2013 & 63 & 3 & $12.5(3.0)$ & $1.7(0.5)$ \\
Period 4 (CT0) & 21 May 2013-25 June 2013 & 36 & 0 & $15.2(2.9)$ & $2.0(0.1)$ \\
\hline 1 Temperature inside the naturally ventilated barn; ${ }^{2}$ Wind speed measured at the weather station outside the \\
barn building.
\end{tabular}

The concentrations of $\mathrm{NH}_{3}, \mathrm{CH}_{4}$ and $\mathrm{CO}_{2}$ were measured continuously with a photoacoustic Multi-Gas Analyser 1412 and a Multiplexer 1303 (LumaSense Technologies SA, Ballerup, Denmark) via infrared spectroscopy as described by [32]. The accuracy of the Multi-Gas Analyser involved 2-3\% absolute deviation of concentrations, and the detection limits given by the calibration chart of the manufacturer were as follows: $0.14 \mathrm{mg} / \mathrm{m}^{3} \mathrm{NH}_{3}, 0.27 \mathrm{mg} / \mathrm{m}^{3} \mathrm{CH}_{4}$, and $9.34 \mathrm{mg} / \mathrm{m}^{3} \mathrm{CO}_{2}$.

During construction of the barn, gas measurement facilities were installed and the building was adjusted to be upstream of the prevailing western wind direction $\left(210^{\circ}-300^{\circ}\right)$. Concentrations of $\mathrm{CO}_{2}$, $\mathrm{CH}_{4}$, and $\mathrm{NH}_{3}$ were measured and documented continuously. For the detection of the outlet air on the east side (lee) of the barn, eight sampling points were merged to one aggregate sample for each section (S1-S2; Figure 1). The background concentration was measured on the west side (windward) outside the barn (background sampling points; Figure 1). The sampling tubes were located at a height of $4 \mathrm{~m}$ above the feed alley and were equipped with filter orifices to protect them from dust. The air of each section was collected continuously by vacuum pumps (ME 2C, Vacuubrand GmbH + Co. KG, Wertheim, Germany) with a suction capacity of $33 \mathrm{~L} / \mathrm{min}$ through a polytetrafluoroethylene tube in a sample bottle $(600 \mathrm{~mL})$. Every tube $(8 \mathrm{~mm}$ inside diameter) was $100 \mathrm{~m}$ long, and the last $15 \mathrm{~m}$ of the tubes were laid underground to connect the barn with the service room where the equipment was located. This area and the service room were heated (heating cable, A. Rak Wärmetechnik GmbH, Frankfurt am Main, Germany) to minimise the influence of temperature and condensation in the tubes $[4,32]$. Consequently, the air exchange was calculated from a $600-\mathrm{mL}$ sample bottle, which was flushed continuously. The whole tube system was flushed every $10 \mathrm{~s}$. With a sampling interval of 240 to $300 \mathrm{~s}$ for each section, an actual and representative air sample could be ensured. Therefore, a sufficient flushing also for the adhesion of $\mathrm{NH}_{3}$ was ensured. The sampling bottles were flushed continuously ( $33 \mathrm{~L} / \mathrm{min}$ ), and the samples for analysis were taken after the described time intervals. The distance between the sampling bottle and gas analyser was as short as possible (less than $0.5 \mathrm{~m}$ ). Additional information on the experimental setup is given in Schmithausen et al. [32].

Wind velocities, wind direction, air temperature, and humidity were measured outside the building with a weather station at a height of $6 \mathrm{~m}$ on the rooftop (north-west-corner) of the barn (Ahlborn Mess- und Regelungstechnik GmbH, Holzkirchen, Germany and LAMBRECHT meteo $\mathrm{GmbH}$, Göttingen, Germany). Hence, during the whole measurement period, all weather conditions were recorded and the data were stored every four minutes $(n=57,930)$. The gas concentrations for each section were measured every five minutes $(n=48,672)$. To adjust weather conditions and gas concentrations, average hourly values were calculated $(n=3862)$. 
The emission mass flow $(M)$ was calculated using the gas concentration for both outlet $\left(C_{\text {outlet }}\right)$ and background ( $\left.C_{\text {background }}\right)$ air of each respective section. This was done according to Equation (1), whereas the $V R$ of the barn was calculated using Equation (2).

$$
M=V R *\left(C_{\text {outlet }}-C_{\text {background }}\right)
$$

The $V R$ was estimated by means of the $\mathrm{CO}_{2}$ balance method [26-28]. One heat production unit (HPU) was defined as equivalent to 1000 watts (W) of the total heat produced by the animals at $20^{\circ} \mathrm{C}$ ambient temperature [26]. Concentration $(C)$ is the difference between the background and outlet concentration of the examined gas.

$$
V R=\frac{0.200}{\left(C_{\text {outlet }}-C_{\text {background }}\right) * 10^{-6}}
$$

At an individual animal level, the $\mathrm{CO}_{2}$ production rate $\left(\mathrm{m}^{3} / \mathrm{h}\right)$ per HPU during a medium feeding level is 0.185 [26,33]. Pedersen et al. [28] suggested a $\mathrm{CO}_{2}$ production rate per HPU of $0.200 \mathrm{~m}^{3} / \mathrm{h}$ in barns with indoor manure storage over a time period longer than three weeks. Thus, a production rate of $0.200 \mathrm{~m}^{3} / \mathrm{h}$ per HPU was selected. To determine the heat produced by one cow, the following formula was used ([26]; Equation (3)):

$$
H_{p}=5.6 * B W^{0.75}+22 * Y
$$

where $H_{p}$ is the total heat production $(W), B W$ is the body weight of the cow, and $Y$ is the milk yield in $\mathrm{kg}$ per day.

\subsection{Animals and Feeding}

A feeding trial consisting of four experimental periods was conducted with high-yielding dairy cows. By supplementing a commercial product rich in condensed tannins (CT), an attempt was made to decrease methane emissions and improve the animals' nitrogen use efficiency, as previously described by [34]. A total of 96 lactating German Holstein cows (25\% primiparous, 112 days in milk (DIM)) were randomly allocated to one of two groups (control (CON) and experimental group (EXP)) and balanced for means of lactation number, DIM, milk yield, and BW. The animals were housed in Section 1 (CON) and Section 2 (EXP) of the barn. The 169-day feeding trail was divided into four periods, starting with a period (period 1) where both groups were fed the same ration without CT (CT0). During periods 2 and 3, the ration of the EXP was supplemented with $1 \%$ (CT1; period 2$)$ and $3 \%$ of DM (CT3; period 3) of an extract rich in CT made from bark of Acacia mearnsii (declared concentration of CT $0.725 \mathrm{~g} / \mathrm{g}$ DM, Weibull Black, TANAC S.A., Montenegro, Brazil) whereas the ration of CON was unchanged. During period 4, cows in both groups were fed the same ration (СТ0) again (Table 1) [34].

An external rotary milking parlour in a neighbouring building was used to milk the cows twice a day $(0500 \mathrm{~h}$ and $1630 \mathrm{~h})$. Milking times were not included in the emission calculations.

The average daily milk yield at the beginning of the experiment was $36.6 \pm 6.6(\mathrm{~kg} / \mathrm{cow}$ per day \pm SD), and the cows had an average BW of $670 \pm 63.3(\mathrm{~kg} / \mathrm{cow})$. During the whole study, cows were fed a total mixed ration (TMR) consisting of grass silage, maize silage, sugar beet pulp, lucerne hay, concentrate (with CT in the EXP) and a mineral premix calculated for $37 \mathrm{~kg}$ of energy corrected milk (ECM). Rations were mixed once daily in a fodder mix wagon and distributed to and offered in computer-controlled weighing troughs (Waagen Döhrn GmbH \& Co. KG, Wesel, Germany; RIC system, Insentec B.V., Marknesse, The Netherlands) for ad libitum intake. The cows were equipped with transponders on collars that allowed them to be identified at each visit and thus enabled the recording of individual daily feed and water intakes.

The DM of the mixed ration, DMI, milk yield (measured by the milking system), and BW as well as several other variables were measured daily; detailed information about the impact of the CT 
extract on DMI, animal productivity, nitrogen use efficiency and digestibility of rations is reported by Gerlach et al. [34].

\subsection{Data Presentation}

Data presentation of barn-level, i.e., group measurements, was carried out purely descriptively because the overall goal was to establish a general frame applying the two variables wind velocity and wind direction. A valid inclusion of more specific weather conditions and sound statistical evaluation would require all-season measurements which were outside the scope of this study. However, we think that the approach of defining a validity range called data classification criteria (DCC) for the variables of wind velocity and wind direction during long-term measurements at barn level provides a valid basis for continuing experimental studies.

\section{Results}

\subsection{Methodical Consideration}

To obtain representative data specifically for this barn building, only values consistent with the defined DCC were used. These criteria relate to topographical characteristics and architectural adjustment of dairy barns on the farmyard. Therefore, the prevailing angle of wind direction was $210^{\circ}$ to $300^{\circ}$ to realise cross flow ventilation for the building (Figure 2). The weather station on the barn roof provided usable data at wind velocities greater or equal to $0.7 \mathrm{~m} / \mathrm{s}$ (detection limit) $(n=3327)$. Thus, for calculation of each wind direction $(\bar{D})$, only values $\left(D_{i}\right)$ with a wind velocity $\left(V_{i}\right) \geq 0.7 \mathrm{~m} / \mathrm{s}$ were used. To ensure that this average value was not based on individual gusts of wind, the average value was calculated from four or more single values per hour. Furthermore, only wind data with an hourly mean $(\bar{D})$ coming from sectors $210^{\circ}$ to $300^{\circ}$ were used $(n=710)$. Figure 2 shows the frequency distribution of wind direction during the experimental period as hourly means distributed in 16 sectors of $22.5^{\circ}$, respectively. Fewer than one-quarter of the values lay between $210^{\circ}$ and $300^{\circ}$.

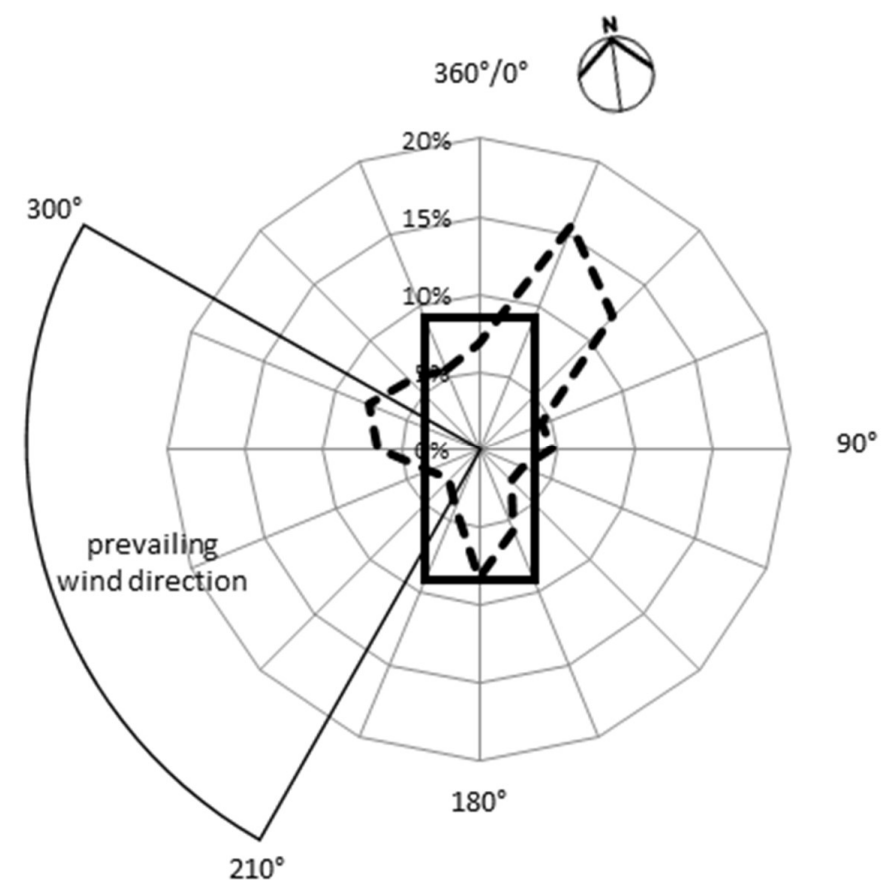

Figure 2. Plot of a wind rose with the selected angle of the upstream flow $\left(210^{\circ}-300^{\circ}\right)$ specific for this barn building to realise cross flow ventilation (solid line: alignment of the barn to the prevailing wind direction; dashed line: frequency of the overall wind direction and a minimum wind velocity $(\geq 0.7 \mathrm{~m} / \mathrm{s})$ per hour over the whole study $(n=3395))$. Compass direction north $(\mathrm{N}) \hat{=} 345^{\circ}$. 


\subsection{Calculation of the Ventilation Rate}

The level of aggregation for the $V R$ was from hourly values which were from a minimum of four individual values of wind speed and suitable wind direction per hour and then averaged to weekly means, because several days occurred in which no data could be measured that fulfilled the DCC. One day equals hours per day minus the milking times in the morning and afternoon; thus, a maximum of $18 \mathrm{~h}$ per day was used. Only data without any further herd management intervention were used for analyses.

Figure 3 depicts the wind velocity and the wind direction over the whole experimental period of 24 weeks. Only $18 \%$ of the overall one-hour values $(n=3862)$ were valid according to the DCC. These hourly means are based on more than four consecutive values. Figure 3 also shows that the frequencies of reliable values during the 24-week period are irregularly distributed. Even longer periods occurred, such as from week 2 to 4 (14-27 January), when the wind velocity was permanently too low or the wind came from the wrong direction to allow reliable measurements.

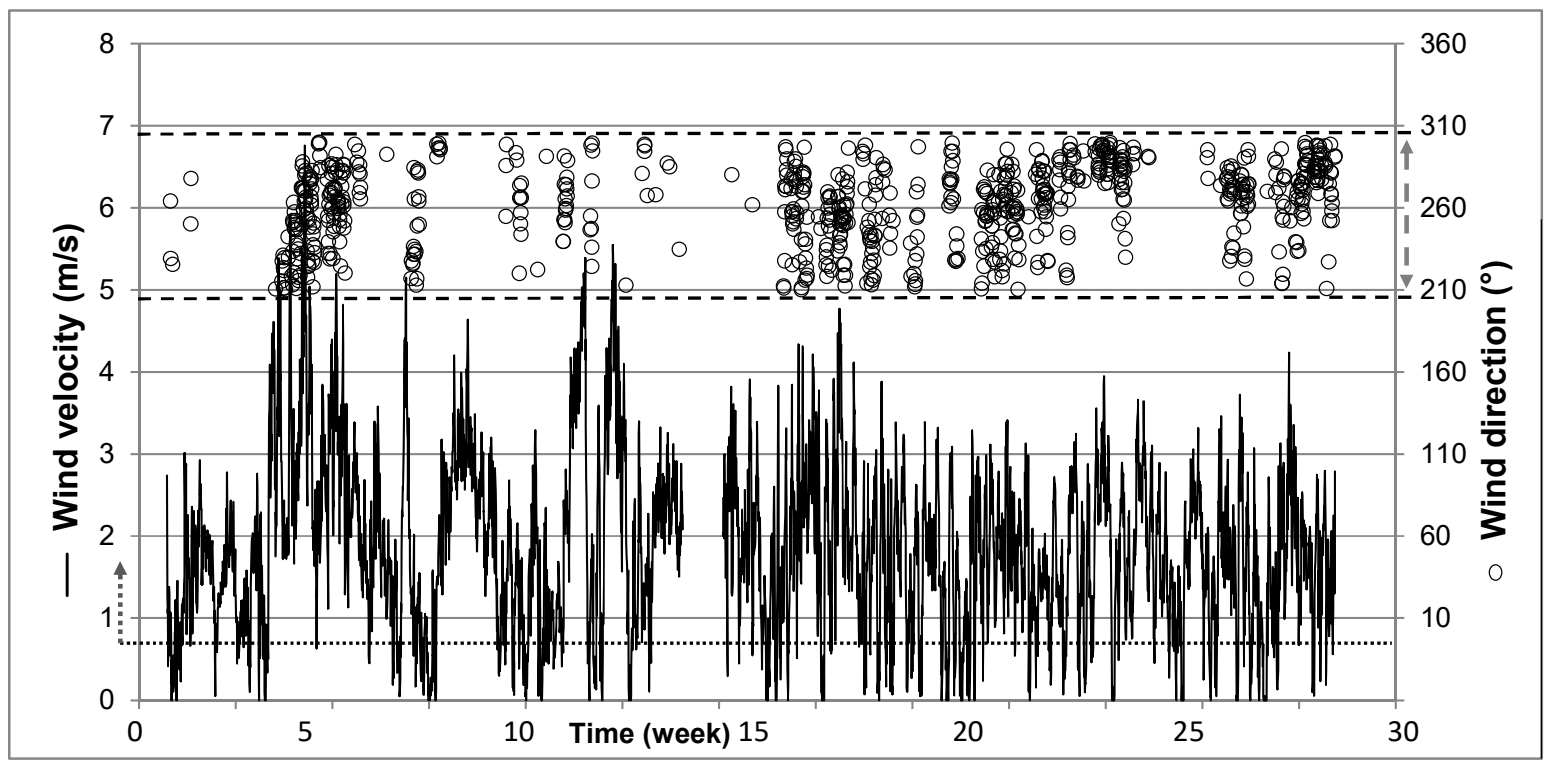

Figure 3. Time axis over 24 weeks (starting point $x$-axis 1 January 2013) with hourly mean values ( $n=4032)$ of wind velocity $(\geq 0.7 \mathrm{~m} / \mathrm{s}$; solid line; $n=3395)$ in the lower part and wind direction (o, open circle) between $210^{\circ}$ and $300^{\circ}(n=710)$ in the upper part of the Figure.

The air exchange rates $\left(\mathrm{m}^{3} / \mathrm{m}^{3}\right.$ per $\left.\mathrm{h}\right)$ of Sections 1 and 2 in comparison with the measured wind velocity $(\mathrm{m} / \mathrm{s})$ at the barn are presented in Figure 4 . Only measurements with closed curtains were considered. A simple regression of the calculated air exchange rate against the wind velocity resulted in an $\mathrm{R}^{2}$ of 0.882 for Section 1 and 0.883 for Section 2. The regression lines clarify the coherence. The initial equation of Section $1(y=18.3 x-8.5)$ had an intercept that was different from zero and, for the ease of comparison, the equation was recalculated and set through the zero point. The equation from Section $2(y=13.8 x-0.86)$ had an intercept that was not different from zero. Similarly, the slope of the line of Section 1 was greater such that, with a wind velocity of $4 \mathrm{~m} / \mathrm{s}$, a $V R$ of $62.9 \mathrm{~m}^{3} / \mathrm{m}^{3}$ per hour was observed compared to $54.1 \mathrm{~m}^{3} / \mathrm{m}^{3}$ per hour for Section 2 . Open curtains at similar wind velocity resulted in higher air exchange rates in the barn (unpublished observations, this study). 


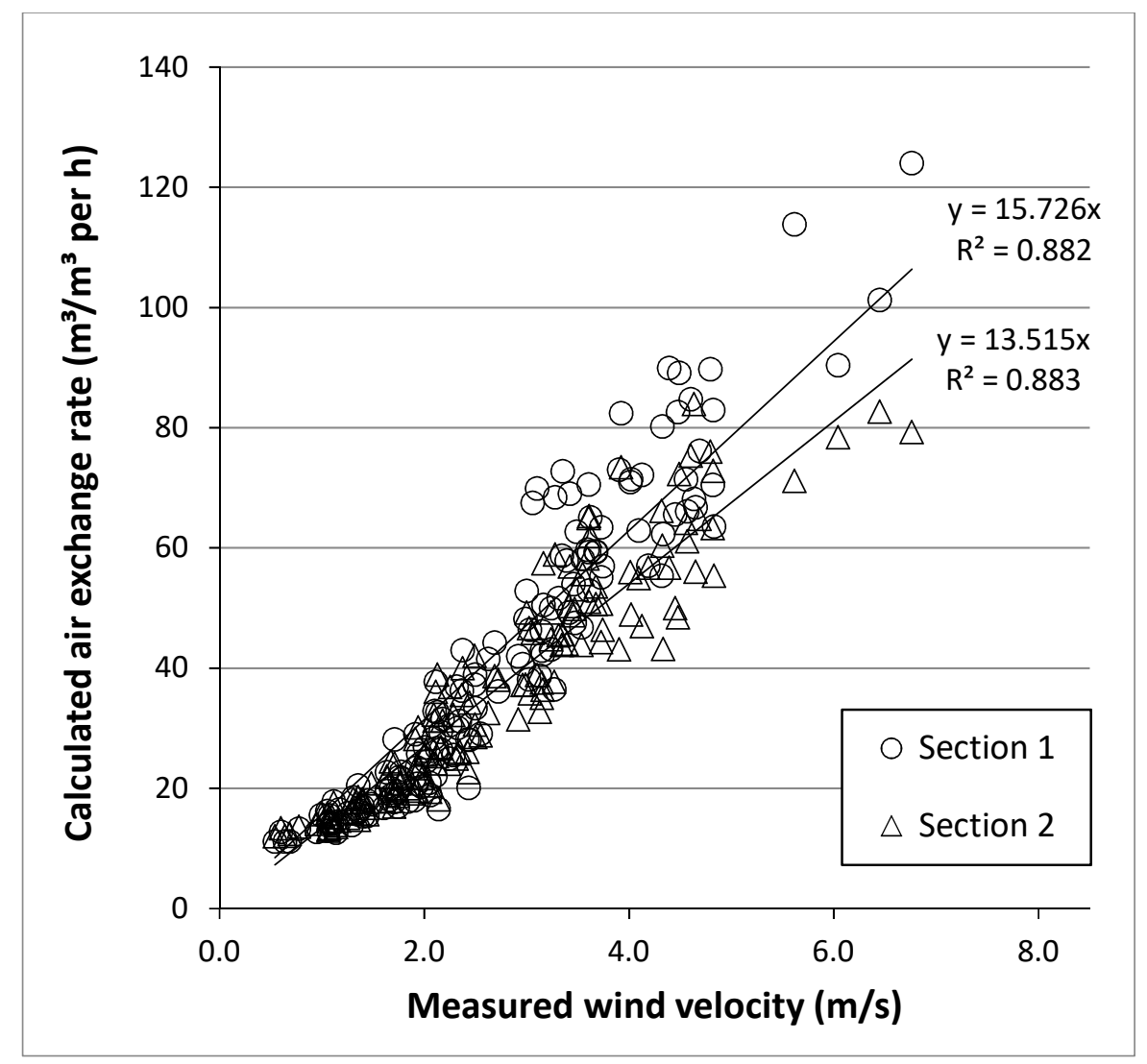

Figure 4. Relationship between the wind velocity $(\mathrm{m} / \mathrm{s})$ and the air exchange rate $\left(\mathrm{m}^{3} / \mathrm{m}^{3}\right.$ per $\left.\mathrm{h}\right)$ in the control group $(\mathrm{CON})$ (Section 1: $\mathrm{SE}=0.232$ ) and experimental group $(\mathrm{EXP})($ Section 2: $\mathrm{SE}=0.176)$ in the winter $(n=149)$ calculated with the $\mathrm{CO}_{2}$ balance method. The point of intersection was set through zero, and the wind velocity on the $x$-axis starts at $0.7 \mathrm{~m} / \mathrm{s}$.

\subsection{Effect of Weather Conditions}

The variations in temperature, $\mathrm{CH}_{4}$ and $\mathrm{NH}_{3}$ emissions over calendar weeks 2 to 25 of 2013 are shown in Figure 5. The $\mathrm{CH}_{4}$ emission rates of both feeding groups decreased, whereas the temperature increased over the course of the measurement periods $\left(4.4^{\circ} \mathrm{C}\right.$ to $15.2^{\circ} \mathrm{C}$; Table 1$)$. In contrast, $\mathrm{NH}_{3}$ emissions from CON increased with increasing temperature from period 1 (18.4 g/LU per day) to period 4 (27.4 g/LU per day) ( $\mathrm{LU}=$ livestock unit $\hat{=} 500 \mathrm{~kg} \mathrm{BW})$, whereas $\mathrm{NH}_{3}$ emissions from EXP were nearly constant from period 2 (23.0 g/LU per day) to period 4 (22.2 g/LU per day; Table 2).

\subsection{Methane and Ammonia Emission Rates Related to Floor Section and Feeding Periods}

Average emission rates of $\mathrm{CH}_{4}$ and $\mathrm{NH}_{3}$ per $\mathrm{LU}$ over four measurement periods are shown in Table 2. No difference was observed between EXP and $\mathrm{CON}$ rations for $\mathrm{CH}_{4}$ emission rates. There was no difference in $\mathrm{NH}_{3}$ emission rates between EXP and CON in periods 1 and 2. In contrast, $\mathrm{NH}_{3}$ emissions from CON, a difference to EXP occurred in period 3 and 4 (Table 2). In period 3, the feeding of tannins (CT3) in EXP decreased $\mathrm{NH}_{3}$ emissions by $34.5 \%$. In period 4 (CT0), $\mathrm{NH}_{3}$ emissions were still lower for EXP cows by $23.4 \%$ (Table 2). Although all cows received the same ration during periods 1 and 4 , in period $1, \mathrm{CH}_{4}$ emissions of $\mathrm{CON}$ cows were lower and $\mathrm{NH}_{3}$ emissions were higher compared to EXP. In period 4, the contrary was observed: lower $\mathrm{CH}_{4}$ emissions of $\mathrm{CON}$ and higher emissions of $\mathrm{NH}_{3}$. 

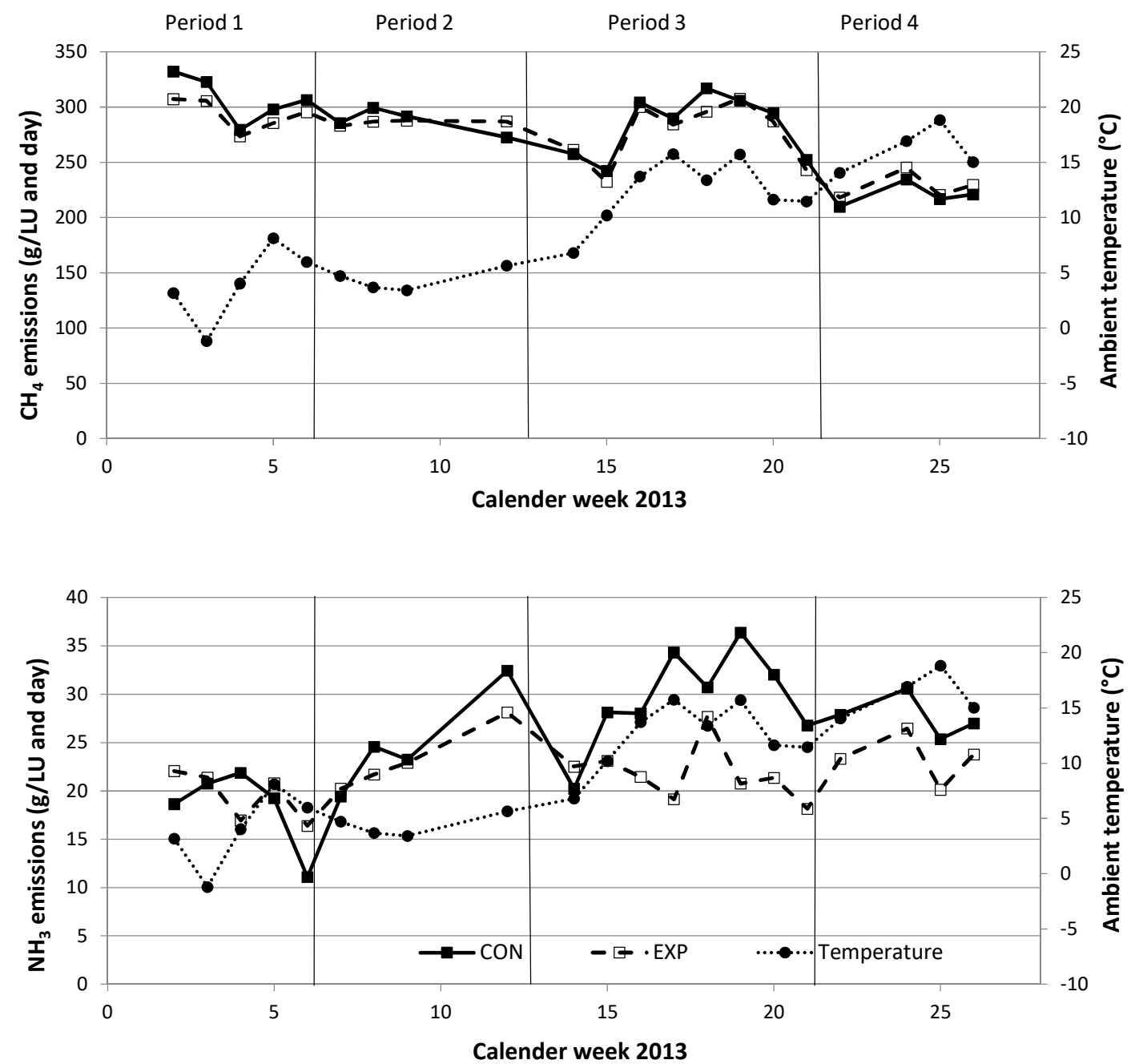

Figure 5. Methane and ammonia emissions of the control (CON; $\square$ ) and experimental (EXP; $\square$ ) groups during four investigation periods (subdivided by vertical bars) with different ambient temperatures $(\bullet)$. Different feed rations are marked with a vertical bar. Data points show weekly means calculated from hourly means (see Section 3.2).

Table 2. Barn level $\mathrm{CH}_{4}$ and $\mathrm{NH}_{3}$ emissions averaged over the feeding periods. GHG: greenhouse gases.

\begin{tabular}{|c|c|c|c|c|c|c|}
\hline \multirow{3}{*}{$\begin{array}{c}\text { Item } \\
\text { Period }\end{array}$} & \multicolumn{6}{|c|}{ GHG in Corresponding Period } \\
\hline & \multicolumn{3}{|c|}{ Methane Emission } & \multicolumn{3}{|c|}{ Ammonia Emission } \\
\hline & $\begin{array}{l}\text { Control group } \\
(\mathrm{CON})\end{array}$ & $\begin{array}{l}\text { Experimental } \\
\text { group (EXP) }\end{array}$ & $\begin{array}{c}\text { CON/EXP } \\
(\%)\end{array}$ & $\begin{array}{c}\text { Control group } \\
(\mathrm{CON})\end{array}$ & $\begin{array}{l}\text { Experimental } \\
\text { group (EXP) }\end{array}$ & $\begin{array}{c}\mathrm{CON} / \mathrm{EXP} \\
(\%)\end{array}$ \\
\hline $\begin{array}{c}\text { Period } 1 \text { (CT0) } \\
\text { g/LU per day (SD) } \\
\text { kg/LU per year }\end{array}$ & $\begin{array}{c}307.1(20.9) \\
112.1\end{array}$ & $\begin{array}{c}291.9(14.3) \\
106.5\end{array}$ & -5.2 & $\begin{array}{c}18.4(4.1) \\
\quad 6.7\end{array}$ & $\begin{array}{c}19.8(2.3) \\
7.2\end{array}$ & +7.1 \\
\hline $\begin{array}{c}\text { Period } 2(\mathrm{CT} 1) \\
\text { g/LU per day }(\mathrm{SD}) \\
\mathrm{kg} / \mathrm{LU} \text { per year }\end{array}$ & $\begin{array}{c}290.6(24.4) \\
106.1\end{array}$ & $\begin{array}{c}289.2(7.9) \\
105.6\end{array}$ & -0.5 & $\begin{array}{c}24.2(9.6) \\
8.9\end{array}$ & $\begin{array}{c}23.0(6.0) \\
8.4\end{array}$ & -5.2 \\
\hline $\begin{array}{c}\text { Period } 3(\mathrm{CT} 3) \\
\text { g/LU per day (SD) } \\
\text { kg/LU per year }\end{array}$ & $\begin{array}{c}289.6(26.1) \\
105.7\end{array}$ & $\begin{array}{c}282.8(24.7) \\
103.2\end{array}$ & -2.4 & $\begin{array}{c}30.0(4.9) \\
10.9\end{array}$ & $\begin{array}{c}22.3(2.5) \\
8.1\end{array}$ & -34.5 \\
\hline $\begin{array}{l}\text { Period } 4 \text { (CT0) } \\
\text { g/LU per day (SD) } \\
\text { kg/LU per year }\end{array}$ & $\begin{array}{c}225.1(13.8) \\
82.2\end{array}$ & $\begin{array}{c}229.6(11.0) \\
83.8\end{array}$ & +2.0 & $\begin{array}{c}27.4(2.0) \\
10.0\end{array}$ & $\begin{array}{c}22.2(3.5) \\
8.1\end{array}$ & -23.4 \\
\hline
\end{tabular}

$\mathrm{LU}=$ livestock unit $\hat{=} 500 \mathrm{~kg}$ body weight; CT0 = all groups were fed without supplemented condensed tannins in the ration; $\mathrm{CT} 1=$ experimental group was fed with $1 \%$ condensed tannins in the ration; $\mathrm{CT} 3=$ experimental group was fed with $3 \%$ condensed tannins in the ration. 


\section{Discussion}

\subsection{Methodical Considerations and Calculation of the Ventilation Rate}

Models and databases to evaluate GHG emissions vary widely and are often not clearly defined. For example, Wu et al. [4] reported the effects of climatic factors and the air exchange rate on GHG emissions, but did not define any rules or measurement criteria for data validation. Using the $\mathrm{CO}_{2}$ balance method for measuring the $V R[26,27]$, total emissions from a defined area (dairy barn) can be monitored. Management procedures in a barn can affect measuring emission rates compared to performance characteristics of the animals. For example, floor types, deep litter bedding systems, and indoor manure storage are additional sources of $\mathrm{CO}_{2}$ that must be included in balance calculations [27,33]. Consequently, established criteria (wind velocity and direction) for a valid range of measurement conditions are essential. In the literature, for example, the reference of continuous long-term measurements vary between measuring periods from some days [18] to several weeks [22,30,35] or even from four months [17] to 19 months [6].

In this study, long-term measurements (169 days) of $\mathrm{CH}_{4}$ and $\mathrm{NH}_{3}$ emission rates calculated by the $\mathrm{CO}_{2}$ balance method [26-28] enabled measurements at a practical scale in a dairy barn. Effects such as outgassing from the excrements during the milking times when the cows were outside the barn has been considered. Furthermore, the method allowed adjustments for different variables such as the BW of the cows and the milk yield [4], such that changes in feeding level and their effects could be estimated. Furthermore, $\mathrm{Wu}$ et al. [4] favoured the $\mathrm{CO}_{2}$ balance method over the tracer gas decay method for the estimation of gas emissions, considering that the cows provide a good mix of $\mathrm{CO}_{2}$ in the barn air. Subsequently, the produced $\mathrm{CO}_{2}$ is an optimal point of reference. Additionally, the DMI between Sections 1 and 2 was similar in this experiment [34], such that not only was the ration well defined, but also the $\mathrm{CO}_{2}$ production was similar.

In this study, the selected barn allowed for the measurement of GHG emissions of two feeding groups (EXP and CON) within the same barn simultaneously (case-control conditions). The measurement frequency (every four minutes at the same measuring point; 15 values per hour) provides an accurate assessment in the differences between the feeding groups, and reduces feasible inaccuracy in the measurement technique.

One major result of this study was that the DCC have a significant influence on the validity of the emission rate estimates of the whole barn. The established characteristics of the DCC show that some periods of measured data (Figure 3) are unsuitable for a naturally ventilated barn with a prevailing wind direction. The findings confirm that measurements in naturally ventilated dairy barns should be carried out for as long as necessary in order to obtain a sufficient number of data points without the confounding influence of, for example, weather conditions. Therefore, short-term or spot measurements are more inconclusive than long-term investigations. In this study, only about $12 \%$ of averaged emission data $\left(\mathrm{CH}_{4}\right.$ and $\left.\mathrm{NH}_{3}\right)$ were categorised as reliable and accurate when judged by wind velocity and wind direction as established by the DCC. As another result of this study, the measurement conditions within both sections of the barn are congruent, which guaranteed equally robust and reliable data for groups of cows receiving treatments that differ between barn sections. The relationship between wind velocity and air exchange rate demonstrated an accurate coherence between both groups (Figure 4). Small differences in air exchange rate $\left(8.8 \mathrm{~m}^{3} / \mathrm{m}^{3}\right.$ per h) between Sections 1 and 2 are regularly occurring and are probably effected by thermal events. Such differences can vary in response to curtain position and effect of wind vector. Therefore, it is recommended to apply key variables (DCC) in different types of buildings to derive building-specific data using the $\mathrm{CO}_{2}$ balance method under case-control conditions and to get more reliable data that may eventually serve as a standard for gaseous emissions from livestock facilities. 


\subsection{Effect of Weather Conditions}

Weather conditions have a large impact on GHG emissions. Ammonia emissions increase with increasing temperature [33,35]. Rong et al. [35] observed a range between $4.53 \mathrm{~g} \mathrm{NH}_{3} / \mathrm{HPU}$ per day (ambient: $7.8^{\circ} \mathrm{C}$ ) and $17.72 \mathrm{~g} \mathrm{NH}_{3} / \mathrm{HPU}$ per day (ambient: $19.9^{\circ} \mathrm{C}$ ). In this study, the $\mathrm{NH}_{3}$ emission rate of $\mathrm{CON}$ cows increased from period 1 to period 3 concurrently with the average temperature. In contrast, the $\mathrm{NH}_{3}$ emission rate of the EXP cows was unaffected by temperature. Thus, it was assumed that the EXP ration reduced $\mathrm{NH}_{3}$ emissions compared to the CON. In contrast, no effect was observed of the temperature on $\mathrm{CH}_{4}$ emissions. In contrast, Pereira et al. [36] observed a significant increase in $\mathrm{CH}_{4}$ production from dairy cattle excreta with change in storage temperature from 5 to $35^{\circ} \mathrm{C}$. Zhang et al. [33] also reported a greater correlation between temperature and $\mathrm{NH}_{3}$ emissions than of temperature and $\mathrm{CH}_{4}$ emissions. Still, it is recommended to measure simultaneously weather conditions for the experimental area and the climate conditions in an experimental building or on commercial farms and especially to distinguish between the storage areas of the slurry. Storage underneath the slatted floor within a building is much less influenced by ambient atmosphere than storage outside under varying and shifting weather conditions [37].

\subsection{Methane and Ammonia Emission Rates Related to Floor Section and Feeding Periods}

The calculated $\mathrm{CH}_{4}$ emission rates were similar to previous studies $[8,17,35]$. However, the present study only focused on those hours per day (maximum of $n=18$ ) without the potential influence on the data of management (e.g., feeding and milking time, slurry homogenisation, cleaning of the walking alleys and bedding areas). Data obtained during these time periods were excluded, because the dairy cows which served as a basis for the $\mathrm{CO}_{2}$ balance method were outside the barn. The $\mathrm{CH}_{4}$ emission rate was similar to that found by Cortus et al. [6], who reported an average $\mathrm{CH}_{4}$ emission of $290 \mathrm{~g} / \mathrm{animal}$ unit ( $\hat{=} 464 \mathrm{~kg} \mathrm{BW}$ ) per day during 20 months of sampling in dairy barns with solid floors.

In this study, no differences in the $\mathrm{CH}_{4}$ emission rate between EXP and $\mathrm{CON}$ were found in any periods. These results disagree with other studies: Grainger et al. [38] using the tracer gas technique, reported a reduction in the range of 10 to $22 \%$ ( $\mathrm{g} \mathrm{CH}_{4} / \mathrm{kg}$ DMI) by supplementing $0.9 \%$ and $1.8 \%$ of DMI of Acacia mearnsii CT to the ration of grazing dairy cows. Measurements taken over some days where higher concentrations of tanniferous extracts in rations were applied decreased $\mathrm{CH}_{4}$ emissions [39,40]. In a comprehensive review of mitigation options, Hristov et al. [40] reported a low $\mathrm{CH}_{4}$ mitigation effect $(<10 \%)$ of $\mathrm{CT}$ and noted a lack of data regarding long-term studies on effects of CT.

The $\mathrm{NH}_{3}$ emissions across all periods (18.4-30.0 $\mathrm{g} \mathrm{NH}_{3} / \mathrm{LU}$ per day) were higher than those reported by Rong et al. [35]. Although there was no effect on $\mathrm{NH}_{3}$ emissions when $1 \% \mathrm{CT}$ extract was fed (period 2; CT1), feeding 3\% CT in the ration (period 3; CT3) decreased the $\mathrm{NH}_{3}$ emission rate by $34.5 \%$. However, in comparison with period 1 , during period 4 (CT0) the $\mathrm{NH}_{3}$ emissions in $\mathrm{CON}$ were still higher. Furthermore, they were only $8.6 \%$ lower than in period 3 . This indicates that the mitigation effect was persistent during the feeding periods and lasted until period 4 , when all cows were again fed the same ration. In period 4, the animal-based variables such as $\mathrm{N}$ in milk decreased much faster than the $\mathrm{NH}_{3}$ emissions within the barn [34]. Probably, in addition to the temperature effect, the effect of longer-lasting $\mathrm{NH}_{3}$ emissions was caused by slurry stored below the slatted floor in the EXP and CON groups. Grainger et al. [38] reported a shift in excreted N from urine to faeces as a response to $\mathrm{CT}$ supplementation. Urea, the soluble and rapidly degradable $\mathrm{N}$ compound in urine, causes a fast release of $\mathrm{NH}_{3}$. Vice versa, when, at the same $\mathrm{N}$ intake, excreted $\mathrm{N}$ is shifted to faeces, continuous emissions from the surface crust of the stored slurry will increase [29,41].

Compared with the statements of Montes et al. [41], the overall emission rates of $\mathrm{NH}_{3}$ for the EXP and CON groups can also, in part, be attributed to the permanent under floor storage of slurry [41]. The focus of this study was to characterise the mitigation potential and not the absolute emission rates based on the comparison of two feeding groups and their emissions within the same building. 


\section{Conclusions}

The study describes defined criteria for calculating the emission rates of a naturally ventilated dairy barn housed with dairy cows in Germany. To date, little attention has been paid to the accuracy of long-term measurements including the corresponding varying basal conditions. The experiment made it possible to quantify gaseous emissions on a herd level, and the results demonstrate that the photoacoustic system is suitable for measuring $\mathrm{CH}_{4}$ and $\mathrm{NH}_{3}$ for long-term measurements in dairy barns. The amount of reliable, utilisable data showed that a definition of the length of measurement periods is indispensable. The applied criteria are unique for each building and need to be considered on different barns in further research. The results of the emission values showed mitigation effects of $\mathrm{NH}_{3}(34.5 \%)$ during feeding 3\% of DM of condensed tannins (Acacia mearnsii) in the ration on herd level, whereas $\mathrm{CH}_{4}$ was not affected. Therefore, such long-term experiments on a practical scale provide more information on the long-term effects of feed additives for ruminants.

Author Contributions: I.S., K.-H.S., K.G., M.P. and W.B. conceived and designed the experiments; I.S. and A.J.S. performed the experiments; A.J.S. and M.T. analyzed the data; A.J.S. contributed reagents/materials/analysis tools; A.J.S. wrote the paper and all co-authors commented on and discussed the manuscript.

Acknowledgments: The authors gratefully acknowledge the support during measurements provided by the team of the research facility 'Haus Riswick', Kleve. The study was partly funded by the German Research Foundation (DFG; BU 1235/8-1) and the Landwirtschaftliche Rentenbank (Z-20039/-7). Manuel Stephan Krommweh is acknowledged for technical support and comments on earlier versions of this manuscript.

Conflicts of Interest: The authors declare no conflict of interest.

\section{References}

1. FAO. Livestock's Long Shadow-Environmental Issues and Options; Food and Agriculture Organization of the United Nations: Rome, Italy, 2006. Available online: http:/ /www.fao.org/docrep/010/a0701e/a0701e00. HTM (accessed on 18 January 2018).

2. Owen, J.J.; Silver, W.S. Greenhouse gas emissions from dairy manure management: A review of field-based studies. Glob. Chang. Biol. 2015, 21, 550-565. [CrossRef] [PubMed]

3. European Economic Area (EEA). European Union Emission Inventory Report 1990-2013 under the UNECE Convention on Long-Range Transboundary Air Pollution 2015; EEA Technical Report No. 8/2015; European Economic Area (EEA): København, Denmark, 2015.

4. Wu, W.; Zhang, G.; Kai, P. Ammonia and methane emissions from two naturally ventilated dairy cattle buildings and the influence of climatic factors on ammonia emissions. Atmos. Environ. 2012, 61, 232-243. [CrossRef]

5. Ngwabie, N.M.; Vanderzaag, A.; Jayasundara, S.; Wagner-Riddle, C. Measurements of emission factors from a naturally ventilated commercial barn for dairy cows in a cold climate. Biosyst. Eng. 2014, 127, $103-114$. [CrossRef]

6. Cortus, E.L.; Jacobson, L.D.; Hetchler, B.P.; Heber, A.J.; Bogan, B.W. Methane and nitrous oxide analyzer comparison and emissions from dairy freestall barns with manure flushing and scraping. Atmos. Environ. 2015, 100, 57-65. [CrossRef]

7. Joo, H.S.; Ndegwa, P.M.; Heber, A.J.; Ni, J.-Q.; Bogan, B.W.; Rmirez-Dorronsoro, J.C.; Cortus, E. Greenhouse gas emissions from naturally ventilated freestall dairy barns. Atmos. Environ. 2015, 102, 384-392. [CrossRef]

8. Samer, M.; Loebsin, C.; Fiedler, M.; Ammon, C.; Berg, W.; Sanftleben, P.; Brunsch, R. Heat balance and tracer gas technique for airflow rates measurement and gaseous emissions quantification in naturally ventilated livestock buildings. Energy Build. 2011, 43, 3718-3728. [CrossRef]

9. Storm, I.M.L.D.; Hellwing, A.L.F.; Nielsen, A.I.; Madsen, J. Methods for measuring and estimating methane emission from ruminants. Animals 2012, 2, 160-183. [CrossRef] [PubMed]

10. Intergovernmental Panel on Climate Change (IPCC). IPCC Guidelines for National Greenhouse Gas Inventories. In National Greenhouse Gas Inventories Program; Eggleston, H.S., Buendia, L., Miwa, K., Ngara, T., Tanabe, K., Eds.; Institute for Global Environmental Strategies (IGES): Hayama, Kanagawa, Japan, 2006. Available online: http:/ / www.ipcc-nggip.iges.or.jp/public/2006gl/pdf/4_Volume4/V4_10_Ch10_Livestock.pdf (accessed on 18 January 2018). 
11. Hill, J.; McSweeney, C.; Wright, A.D.G.; Bishop-Hurley, G.; Kalantar-Zadeh, K. Measuring methane production from ruminants. Trends Biotechnol. 2016, 34, 26-35. [CrossRef] [PubMed]

12. Madsen, J.; Bjerg, B.S.; Hvelplund, T.; Weisbjerg, M.R.; Lund, P. Methane and carbon dioxide ratio in excreted air for quantification of the methane production from ruminants. Livest. Sci. 2010, 129, 223-227. [CrossRef]

13. Huhtanen, P.; Cabezas-Garcia, E.H.; Utsumi, S.; Zimmerman, S. Comparison of methods to determine methane emissions from dairy cows in farm conditions. J. Dairy Sci. 2015, 98, 3394-3409. [CrossRef] [PubMed]

14. Troy, S.H.; Duthie, C.-A.; Ross, D.W.; Hyslop, J.J.; Roehe, R.; Waterhouse, A.; Rooke, J.A. A comparison of methane emissions from beef cattle measured using methane hoods with those measured using respiration chambers. Anim. Feed Sci. Technol. 2016, 211, 227-240. [CrossRef]

15. Hristov, A.N.; Oh, J.; Giallongo, F.; Frederick, T.; Weeks, H.; Zimmerman, P.R.; Harper, M.T.; Hristova, A.; Zimmerman, R.S.; Branco, A.F. The use of an automated system (GreenFeed) to monitor enteric methane and carbon dioxide emissions from ruminant animals. J. Vis. Exp. 2015, 103, e52904. [CrossRef] [PubMed]

16. The National Academies Press. National Academies of Sciences, Engineering, and Medicine. Improving Characterization of Anthropogenic Methane Emissions in the United States; The National Academies Press: Washington, DC, USA, 2018.

17. Ngwabie, N.M.; Jeppsson, K.H.; Nimmermark, S.; Swensson, C.; Gustafsson, G. Multi-location measurements of greenhouse gases and emission rates of methane and ammonia from a naturally-ventilated barn for dairy cows. Biosyst. Eng. 2009, 103, 68-77. [CrossRef]

18. Pereira, J.; Fangueiro, D.; Misselbrook, T.H.; Chadwick, D.R.; Coutinho, J.; Trindade, H. Ammonia and greenhouse gas emissions from slatted and solid floors in dairy cattle houses: A scale model study. Biosyst. Eng. 2011, 109, 148-157. [CrossRef]

19. Schrade, S.; Zeyer, K.; Gygax, L.; Emmenegger, L.; Hartung, E.; Keck, M. Ammonia emissions and emission factors of naturally ventilated dairy housing with solid floors and an outdoor exercise area in Switzerland. Atmos. Environ. 2012, 47, 183-194. [CrossRef]

20. Samer, M.; Ammon, C.; Loebsin, C.; Fiedler, M.; Berg, W.; Sanftleben, P.; Brunsch, R. Moisture balance and tracer gas technique for ventilation rates measurement and greenhouse gases and ammonia emissions quantification in naturally ventilated buildings. Build. Environ. 2012, 50, 10-20. [CrossRef]

21. Demmers, T.G.M.; Phillips, V.R.; Short, L.S.; Burgess, L.R.; Hoxey, R.P.; Wathes, C.M. Validation of ventilation rate measurement methods and the ammonia emission from naturally ventilated dairy and beef buildings in the United Kingdom. J. Agric. Eng. Res. 2001, 79, 107-116. [CrossRef]

22. Samer, M.; Muller, H.J.; Fiedler, M.; Ammon, C.; Glaser, M.; Berg, W.; Sanftleben, P.; Brunsch, R. Developing the $(85) \mathrm{Kr}$ tracer gas technique for air exchange rate measurements in naturally ventilated animal buildings. Biosyst. Eng. 2011, 109, 276-287. [CrossRef]

23. Demmers, T.G.M.; Burgess, L.R.; Phillips, V.R.; Clark, J.A.; Wathes, C.M. Assessment of techniques for measuring the ventilation rate, using an experimental building section. J. Agric. Eng. Res. 2000, 76, 71-81. [CrossRef]

24. Snell, H.G.J.; Seipelt, F.; Van den Weghe, H.F.A. Ventilation rates and gasous emissions from naturally ventilated dairy houses. Biosyst. Eng. 2003, 86, 67-73. [CrossRef]

25. Ogink, N.W.M.; Mosquera, J.; Calvet, S.; Zhang, G. Methods for measuring gas emissions from naturally ventilated livestock buildings: Developments over the last decade and perspectives for improvement. Biosyst. Eng. 2013, 116, 297-308. [CrossRef]

26. Commission International Du Genie Rural (CIGR). Report of Working Group on Climatization of Animal Houses-Heat and Moisture Production at Animal and House Levels; Pedersen, S., Sällvik, K., Eds.; Commission International Du Genie Rural (International Commission of Agricultural Engineering): Horsens, Denmark, 2002; pp. 1-46.

27. Pedersen, S.; Takai, H.; Johnsen, J.O.; Metz, J.H.M.; Koerkamp, P.; Uenk, G.H.; Phillips, V.R.; Holden, M.R.; Sneath, R.W.; Short, J.L.; et al. A comparison of three balance methods for calculating ventilation rates in livestock buildings. J. Agric. Eng. Res. 1998, 70, 25-37. [CrossRef]

28. Pedersen, S.; Blanes-Vidal, V.; Joergensen, H.; Chwalibog, A.; Haeussermann, A.; Heetkamp, M.J.W.; Aarnink, A.J.A. Carbon Dioxide Production in Animal Houses: A Literature Review. Agricultural Engineering International, CIGR Ejournal, 2008. Available online: http://www.cigrjournal.org/index. $\mathrm{php} /$ Ejounral/article/view/1205/1132 (accessed on 18 January 2018). 
29. Gerber, P.J.; Hristov, A.N.; Henderson, B.; Makkar, H.; Oh, J.; Lee, C.; Meinen, R.; Montes, F.; Ott, T.; Firkins, J.; et al. Technical options for the mitigation of direct methane and nitrous oxide emissions from livestock: A review. Animal 2013, 7, 220-234. [CrossRef] [PubMed]

30. Saha, C.K.; Ammon, C.; Berg, W.; Fiedler, M.; Loebsin, C.; Sanftleben, P.; Brunsch, R.; Amon, T. Seasonal and diel variations of ammonia and methane emissions from a naturally ventilated dairy building and the associated factors influencing emissions. Sci. Total Environ. 2014, 468-469, 53-62. [CrossRef] [PubMed]

31. Hempel, S.; Saha, C.K.; Fiedler, M.; Berg, W.; Hansen, C.; Amon, B.; Amon, T. Non-linear temperature dependency of ammonia and methane emissions from a naturally ventilated dairy barn. Biosyst. Eng. 2016, 145, 10-21. [CrossRef]

32. Schmithausen, A.J.; Trimborn, M.; Büscher, W. Methodological comparison between a novel automatic sampling system for gas chromatography versus photoacoustic spectroscopy for measuring greenhouse gas emissions under field conditions. Sensors 2016, 16, 1638. [CrossRef] [PubMed]

33. Zhang, G.; Strom, J.S.; Li, B.; Rom, H.B.; Morsing, S.; Dahl, P.; Wang, C. Emission of ammonia and other contaminant gases from naturally ventilated dairy cattle buildings. Biosyst. Eng. 2005, 92, 355-364. [CrossRef]

34. Gerlach, K.; Pries, M.; Tholen, E.; Schmithausen, A.J.; Büscher, W.; Südekum, K.-H. Effect of condensed tannins in rations of lactating dairy cows on production variables and nitrogen use efficiency. Animal 2018. [CrossRef] [PubMed]

35. Rong, L.; Liu, D.; Pedersen, E.F.; Zhang, G. Effect of climate parameters on air exchange rate and ammonia and methane emissions from a hybrid ventilated dairy cow building. Energy Build. 2014, 82, 632-643. [CrossRef]

36. Pereira, J.; Misselbrook, T.H.; Chadwick, D.R.; Coutinho, J.; Trindade, H. Effect of temperature and dairy cattle excreta characteristics on potential ammonia and greenhouse gas emissions from housing: A laboratory study. Biosyst. Eng. 2012, 122, 138-150. [CrossRef]

37. Sommer, S.G.; Zhang, G.Q.; Bannink, A.; Chadwick, D.; Misselbrook, T.; Harrison, R.; Hutchings, N.J.; Menzi, H.; Monteny, G.J.; Ni, J.Q.; et al. Algorithms determining ammonia emission from buildings housing cattle and pigs and from manure stores. Adv. Agron. 2006, 89, 261-335.

38. Grainger, C.; Clarke, T.; Auldist, M.J.; Beauchemin, K.A.; McGinn, S.M.; Waghorn, G.C.; Eckard, R.J. Potential use of Acacia mearnsii condensed tannins to reduce methane emissions and nitrogen excretion from grazing dairy cows. Canadian J. Anim. Sci. 2009, 89, 241-251. [CrossRef]

39. Flachowsky, G.; Lebzien, P. Effects of phytogenic substances on rumen fermentation and methane emissions: A proposal for a research process. Anim. Feed Sci. Technol. 2012, 176, 70-77. [CrossRef]

40. Hristov, A.N.; Oh, J.; Firkins, J.L.; Dijkstra, J.; Kebreab, E.; Waghorn, G.; Makkar, H.P.S.; Adesogan, A.T.; Yang, W.; Lee, C.; et al. Special topics-Mitigation of methane and nitrous oxide emissions from animal operations: I. A review of enteric methane mitigation options. J. Anim. Sci. 2013, 91, 5045-5069. [PubMed]

41. Montes, F.; Meinen, R.; Dell, C.; Rotz, A.; Hristov, A.N.; Oh, J.; Waghorn, G.; Gerber, P.J.; Henderson, B.; Makkar, H.P.S.; et al. Special topics-Mitigation of methane and nitrous oxide emissions from animal operations: II. A review of manure management mitigation options. J. Anim. Sci 2013, 91, 5070-5094. [PubMed]

(c) 2018 by the authors. Licensee MDPI, Basel, Switzerland. This article is an open access article distributed under the terms and conditions of the Creative Commons Attribution (CC BY) license (http://creativecommons.org/licenses/by/4.0/). 